HEGELIAN REFLECTIONS ON THE IDEA OF NUCLEAR WAR 


\section{Hegelian Reflections on the Idea of Nuclear War}

Dialectical Thinking and the Dialectic of Mankind

Hayo B. E. D. Krombach

Palgrave Macmillan 
ISBN 978-1-349-11614-0 ISBN 978-1-349-11612-6 (eBook)

DOI 10.1007/978-1-349-11612-6

(C) Hayo B. E. D. Krombach 1991

Softcover reprint of the hardcover 1st edition 1991

All rights reserved. For information, write:

Scholarly and Reference Division,

St. Martin's Press, Inc., 175 Fifth Avenue,

New York, N.Y. 10010

First published in the United States of America in 1991

ISBN 978-0-312-04845-7

Library of Congress Cataloging-in-Publication Data

Krombach, Hayo B. E. D., 1945-

Hegelian reflections on the idea of nuclear war : dialectical thinking and the dialectic of mankind / Hayo B. E. D. Krombach. p. $\mathrm{cm}$.

Includes bibliographical references.

ISBN 978-0-312-04845-7

1. Nuclear warfare - Philosophy. 2. Hegel, Georg Wilhelm Friedrich, 1770-1831 - Contributions in philosophy of political science. 3. Hegel, Georg Wilhelm Friedrich, 1770-1831 Contributions in dialectic. 4. Political science-Philosophy. 5. Dialectic. I. Title.

U263.K76 1991

$355.02 ' 17-\mathrm{dc} 20$

90-8518

CIP 
To the memory of my father 


\section{Contents}

Preface $\quad$ xi

Introduction 1

Part I SCIENTIFIC DIALECTIC 9

1 Antiquity 11

Plato's Dialectical Dialogue $\quad 12$

Aristotle's Dialectical Deduction $\quad 27$

Summary $\quad 40$

2 Modernity 42

Popper's Objective Dialectic of Falsification $\quad 43$

Kuhn's Subjective Dialectic of Paradigms $\quad 50$

Feyerabend's Dissolution of Scientific Dialectic $\quad 57$

Summary $\quad 65$

Part II HISTORICAL DIALECTIC 67

3 Hegel's Logic of Dialectic 69

Understanding and Reason $\quad 71$

$\begin{array}{ll}\text { Feyerabend and Hegel } & 78\end{array}$

Philosophical Speculation $\quad 88$

Negative and Positive Reason $\quad 97$

Formal and Concrete Logic 104

Ground as Ontology and Logic 108

Substance and Subject $\quad 113$

Method and System 118

The Application of Logic $\quad 129$

Summary 132

4 Hegel's Phenomenon of Logic 134

The Idea of Mankind as Life $\quad 135$

The Differentiations of Mankind 148

The Historical Judgment $\quad 158$

$\begin{array}{ll}\text { The State } & 167\end{array}$

The Reflection of the State 173

The Development of State-Reflection $\quad 180$

The Formation of the States-System $\quad 187$ 
The Determination of the States-System 200

The Development of the States-System 204

Summary 220

Part III THE SCIENTIFIC DISSOLUTION OF HISTORY 223

5 The End of Hegel's Dialectic 225

Mankind Sublated 225

Mankind Annihilated $\quad 231$

Summary 239

6 The Dialectical Relation between War and Peace 241

State Relations $\quad 241$

The Idea of War 244

The Responsibility for Peace 248

Summary 254

Conclusion 255

$\begin{array}{ll}\text { Abbreviations } & 258\end{array}$

References 261

Bibliography 281

Index $\quad 287$ 
Wo aber Gefahr ist, wächst Das Rettende auch.

Hölderlin 


\section{Preface}

The aim of this book is to reflect in a Hegelian philosophical manner upon the nuclear age. Its more specific purpose is of a two-fold nature. It is to acquaint the reader with the principle of dialectical thinking as it manifests itself in three different though related experiences: in the unfolding of human discourse, in the conceptualisation of scientific methodologies, and in the historical development of selfconsciousness. But, because the meaning of method is mainly demonstrated in its application, the objective of the book is also to use dialectic in the effort to comprehend the idea of nuclear war within its historical context. The intellectual appeal and relevance of the inquiry lie in the philosophical approach to thematise a life in danger of committing suicide, and particularly in the way it interprets and to this effect employs Hegel's principle of historical dialectic.

The book grew out of a doctoral dissertation which was written at the London School of Economics and Political Science under the supervision of Philip Windsor. It was examined by Leszek Kolakowski of All Souls College, University of Oxford and the University of Chicago. I would like to extend to both my warmest thanks for their advice and encouragement to make the material available to a wider audience.

However, in the course of preparing its publication the original thesis had to be substantially condensed and revised. The result is a carefully laid out analysis of dialectic. Not only is the classical Greek tradition accorded in-depth consideration. The reasons are also explained why the concern with dialectical thinking has assumed different forms at various historical junctures, and why we can learn from an intellectual device that is part of our philosophical heritage.

The origin of the ideas which underly the present text goes back to my studies in philosophy at the University of Toronto in the 1970s. The emphasis on the close reading of primary sources, ancient and modern, and their meaningful rendering in the light of different historical horizons was one of the most valuable moments in those early years of academic life. I am therefore much indebted to my former teachers, in particular to R. E. Allen, Allan Bloom, D. P. Gauthier, C. B. Macpherson, R. G. McRae, Graem Nicholson, T. M. Robinson and K. Schmitz.

I became aware of the importance of applying the dialectical 
method to thinking about one of the most difficult problems of international relations during my graduate studies at the Institut Universitaire de Hautes Etudes Internationales at the University of Geneva. I owe special gratitude to Curt Gasteyger whose enlightening and thought-provoking seminar in Strategic Studies made me realise that, apart from the need for thorough empirical research, there is an even greater urgency to ponder the increasingly global implications of inter-state politics and the attendant threat to the integrity of mankind in a way that allows for their philosophical comprehension. After having nearly changed the world beyond recognition, we must again reflect and learn to wonder.

It was then in subsequent years at the LSE that I was offered the opportunity to work with Philip Windsor in the Department of International Relations. Being a truly inspiring educator, whose human wisdom and philosophical insight into the afflictions of the world exert a deep and lasting influence over his students, $\mathrm{Mr}$ Windsor provided me with unfailing moral and intellectual support and guided me patiently through an as yet uncharted field of rumination.

A more direct debt, however, is due to those who have read the final product either as a whole or in part. I have greatly benefited from comments made by Elie Kedourie, Donald McRea, Tom Nossiter and Cyril Smith from the LSE. I would also like to thank Dieter Henrich from the Institut für Philosophie at the Maximilians Universität in Munich for his sincere interest shown in my work. I have profited much from his erudite writings on Hegel and on the ethical problems which the idea of nuclear war poses. These are not only a comment in themselves, but even more so an encouragement to pursue the path of my reflections. A rather distinctive contribution was made by Cyril Smith. In regular and highly rewarding conversations we approached the philosophical problematic of dialectic from a Marxist and Hegelian point of view. Without the dialogue we would not have become aware of our differences. But without the disagreements we would not be united in history either.

For kind permission to quote from Hegel's Science of Logic (trans. A. V. Miller, 1969) and from The Complete Works of Aristotle (ed. John Barnes, 1985) acknowledgement is made with thanks to Unwin Hyman Ltd. and Princeton University Press, respectively. 